\title{
GILL RAKER COUNTING FOR APPROXIMATING THE RATIO OF RIVER- AND SEA- SPAWNING WHITEFISH, COREGONUS LAVARETUS (ACTINOPTERYGII: SALMONIFOR- MES: SALMONIDAE) IN THE GULF OF BOTHNIA, BALTIC SEA
}

\author{
Mikael HIMBERG ${ }^{1}$, Mikael von NUMERS ${ }^{1}$, Anti VASEMÄGI², Sven-Johan HESELIUS ${ }^{3}$, \\ Tom WIKLUND ${ }^{1}$, Jan-Olof LILL ${ }^{3}$, and Henry HÄGERSTRAND ${ }^{1 *}$ \\ ${ }^{1}$ Laboratory of Aquatic Pathobiology and Husö Biological Station, Environmental and Marine Biology, \\ Faculty of Science and Engineering, Åbo Akademi University, Åbo, Finland \\ ${ }^{2}$ Department of Biology, University of Turku, Turku, Finland and Department of Aquaculture, \\ Estonian University of Life Sciences, Tartu, Estonia \\ ${ }^{3}$ Accelerator Laboratory, Turku PET Centre, Åbo Akademi University, Åbo, Finland
}

\begin{abstract}
Himberg M., von Numers M., Vasemägi A., Heselius S.-J., Wiklund T., Lill J.-O., Hägerstrand H. 2015. Gill raker counting for approximating the ratio of river- and sea-spawning whitefish, Coregonus lavaretus (Actinopterygii: Salmoniformes: Salmonidae) in the Gulf of Bothnia, Baltic Sea. Acta Ichthyol. Piscat. 45 (2): 125-131.
\end{abstract}

Background. The ability to distinguish between stocks in mixed fisheries is a prerequisite for a sustainable fisheries management. In the Gulf of Bothnia the relative contribution of endangered river-spawning and sea-spawning whitefish, Coregonus lavaretus (Linnaeus, 1758), to fisheries catches are currently not well known. This also applies to the southern Åland Islands, a major feeding ground for river-spawning whitefish from northern rivers. River- and sea-spawning whitefish are mixed while away from the breeding grounds and off the spawning season, and cannot be distinguished based on external features.

Materials and methods. Analysis on gill raker numbers of river-spawning $(n=480)$ and sea-spawning $(n=456)$ whitefish from twelve locations at the Finnish west coast and the Åland Islands was performed. In whitefish sampled from feeding grounds at the Åland Islands the strontium concentration was analysed in otoliths from fish ( $n$ $=20$ ) with low (27) and high (30) number of gill rakers.

Results. A marked difference in the mean gill raker number of the river- and sea-spawning whitefish stocks was observed. The weighted mean of gill rakers of whitefish caught at spawning locations showed that the number of gill rakers of fish from rivers and the sea were 29.9 $\pm 2.14(n=480)$ and $26.7 \pm 2.21(n=456)$, respectively. The difference between the two groups was highly significant $(t=22.50, \mathrm{df}=934, P<0.0001)$. The means differed by $3.20(2.92-3.48,95 \% \mathrm{CL})$ indicating the groups are well separated. In whitefish sampled at feeding grounds at the Åland Islands, otolith strontium concentration was higher $(t=2.09, \mathrm{df}=18, P=0.04)$ in fish having 27 gill rakers $\left(3.86 \pm 0.30 \mathrm{mg} \cdot \mathrm{g}^{-1}, n=10\right)$, compared to those having 30 gill rakers $\left(3.54 \pm 0.35 \mathrm{mg} \cdot \mathrm{g}^{-1}, n=10\right)$. Otolith strontium analysis thereby supported the utility of gill raker counting data for estimating the proportion of river- and sea-spawning whitefish in mixed populations. As expected, the gill raker counting method successfully indicated temporal alterations in the proportions of river- and sea-spawning whitefish on feeding grounds.

Conclusion. Gill raker counting is an easy, fast, and inexpensive method that can be used to estimate the spatiotemporal occurrence and migratory patterns of river- and sea-spawning whitefish at the southern feeding grounds in the Gulf of Bothnia, and thereby aid in a sustainable management of whitefish stocks.

Keywords: stock discrimination, mixed fisheries, spatiotemporal occurrence, endangered species, otolith strontium

\section{INTRODUCTION}

European whitefish, Coregonus lavaretus (Linnaeus, 1758), occurs in two sympatric forms in the Gulf of Bothnia: an anadromous river-spawning and a sea-spawning form (Lindroth 1957, Svärdson 1957, Himberg 1970,
Valtonen 1970, Himberg 1978, Lehtonen and Himberg 1979, 1992, Lehtonen 1981). River- and sea-spawning whitefish tend to form mixed populations in the sea away from the breeding grounds and off the spawning season (Himberg 1978, Lehtonen and Himberg 1979). Natural 
reproduction of river-spawning whitefish in the Gulf of Bothnia has diminished during the last decades, mainly due to anthropogenic destruction of the spawning habitats (Anonymous 2013). Furthermore, river-spawning whitefish fall victims to fishermen during spawning migration. Similar to river-spawners, the natural reproduction of sea-spawning whitefish is locally disturbed, i.e., along the southern part of the Finnish west coast, apparently due to eutrophication of spawning habitats (Himberg 1995, Vanhatalo et al. 2012, Hudd et al. 2013, Veneranta et al. 2013). In order to preserve river-spawning whitefish populations and maintain abundant stocks for fishing, massive stocking of whitefish has been undertaken in Finland for several decades (Anonymous 2013).

River- and sea-spawning whitefish belong to the demersal coastal fish fauna, and are frequent benthic feeders (Himberg 1995, Verliin et al. 2011). River-spawning whitefish spawn in rivers along the Finnish west coast and can migrate long distances, e.g., between rivers in the north of Finland and Åland Islands in the south $(>700$ km) (Wikgren 1962, Lind and Kaukoranta 1974, Lehtonen 1981, Lehtonen and Himberg 1992). This migration occurs along the Finnish coast (Fig. 1). Rich food sources due to beneficial water temperature, light, and salinity are the probable reasons for the southward migration of river-spawning whitefish, while preferential spawning locations are the driving forces for their returning. At the Åland Islands and the adjacent Archipelago Sea the feeding conditions are particularly beneficial for whitefish, since thousands of small islands and reefs offer a vast area of shores and shallows abundant with food (Lehtonen 1981, Himberg 1995). River-spawning whitefish usually leaves the spawning-rivers and their estuaries for migration towards the south during their first year (Lehtonen and Himberg 1992, Leskelä et al. 2009, Jokikokko et al. 2012). Mature river-spawning whitefish males normally return for spawning at the age of 3-4 years and females at the age of 4-5 years (Lehtonen 1981, Leskelä et al. 2009). The migration from the Åland Island for spawning in the northern rivers starts in June-July, and there may be several migration cycles. A migration speed of up to $15 \mathrm{~km}$ per day has been reported (Wikgren 1962). Sea-spawning whitefish occurs all along the Finnish coast. Sea-spawners normally migrate less than $200 \mathrm{~km}$ and move between deep and shallow water (Dahr 1947, Lehtonen and Himberg 1992). Around the Åland Islands sea-spawning whitefish is highly stationary (Leskelä unpublished*). The spawning locations near the seashore are scattered around the Åland Islands. Both river- and sea-spawning whitefish spawn in October-November.

The spatiotemporal occurrence of river-spawning whitefish and its ratio in whitefish catches at the Aland Islands and the Finnish west coast are not well known, as river-spawning whitefish cannot be distinguished from sea-spawning whitefish based on the external features. However, it has been suggested that on the population level identification is possible by gill raker counting (Him- berg 1978, Lehtonen and Himberg 1979, Lehtonen 1981, Lehtonen and Böhling 1988). The gill raker number is a temporally stable (Svärdson 1957, Amundsen et al. 2004, Bernatchez et al. 2010, Siwertsson et al. 2012) (Table 1) and highly heritable (Kirpichnikov 1981) character. The river-spawning whitefish is characterised by the weighted mean number of 29-30 gill rakers (Järvi 1928, Svärdson 1957, Himberg 1970, Lehtonen 1981). The sea spawning whitefish again is characterised by a lower weighted mean number of gill rakers: 26-27 at the Åland Islands including the Archipelago Sea (Himberg 1970, Lehtonen 1981).

The strontium concentration in seawater increases with salinity (Campana 1999, Elsdon et al. 2008). Since strontium accumulation in otoliths is positively correlated with salinity of the ambient water (Campana 1999, Elsdon et al. 2008, Doubleday et al. 2013), river- and sea-spawning whitefish should be distinguishable from each other based

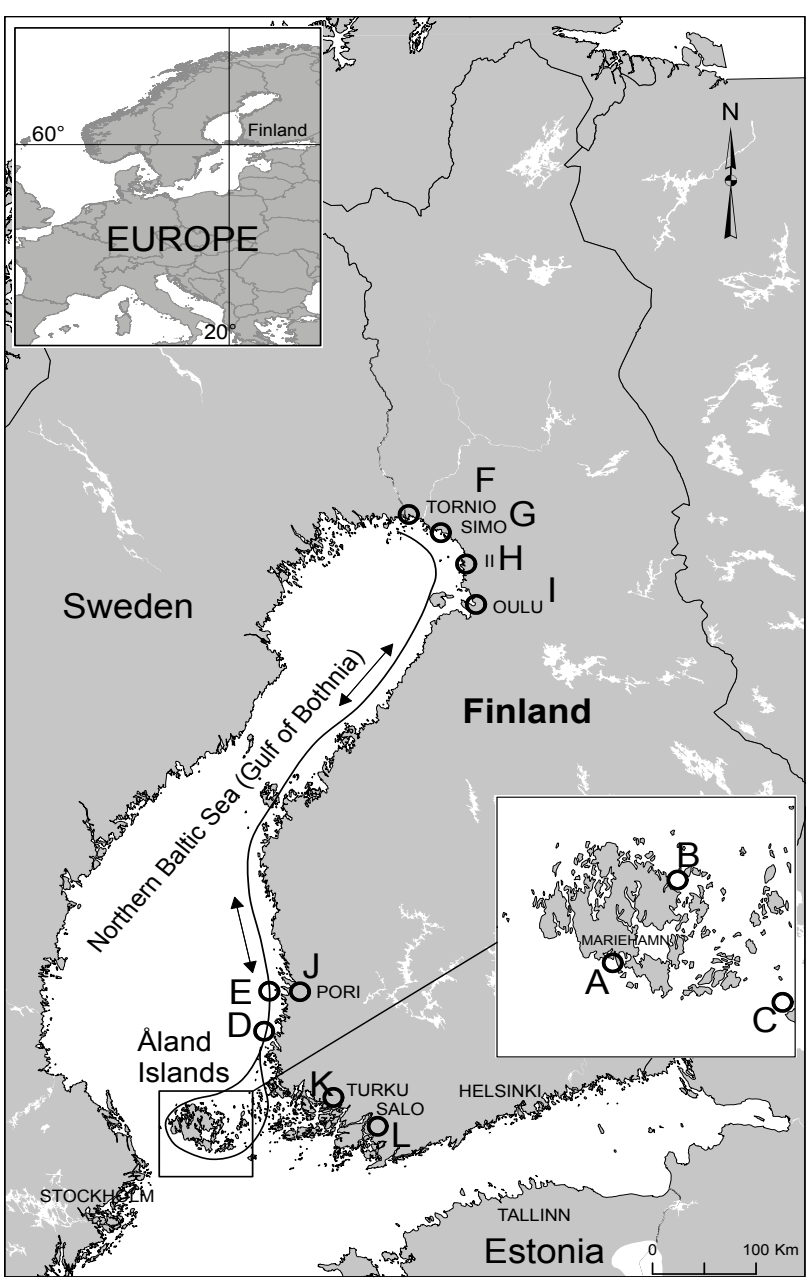

Fig. 1. Sampling sites of European whitefish, Coregonus lavaretus, in the Gulf of Bothnia; A = Kobba Klintar, $\mathrm{B}=$ Tengsöda, $\mathrm{C}=$ Kökar, $\mathrm{D}=$ Pyhäranta, $\mathrm{E}=$ Pori, $\mathrm{F}$ $=$ Tornio River, $\mathrm{G}=$ Simo River, $\mathrm{H}=$ Ii River, $\mathrm{I}=$ Oulu River, $\mathrm{J}=$ Kokemäki River, $\mathrm{K}=$ Aura River, $\mathrm{L}=$ Kisko River; A schematic migration route for river-spawning whitefish along the Finnish west coast is marked by black line and arrows

* Leskelä A. 2008. Resultaten av sikutplantering på Åland. [Results from whitefish stocking at the Åland Islands.] Rapport till Ålands Landskapsregering. [In Swedish.] 
on their otolith strontium concentrations. During early lifetime, at least, river-spawning whitefish spend time in water of low salinity and is therefore expected to have lower otolith strontium levels.

Proper specimen identification is necessary for collecting data on the spatiotemporal occurrence and ratio in catches of river- and sea-spawning whitefish. This study aimed at validating the method of gill raker counting for discriminating between river- and sea-spawning whitefish at the Åland Islands. For this, the gill raker numbers of river- and sea-spawning whitefish stocks were compared, and otolith strontium concentration analysed in a subset of whitefish with low (27) and high (30) number of gill rakers. Our results may help in the administration of whitefish stocks preservation.

\section{MATERIALS AND METHODS}

Study area. The Gulf of Bothnia reaches $\sim 750 \mathrm{~km}$ from the Alland Islands in the south, to the Tornio region in the north (Fig. 1) (Anonymous 2010). It is a shallow sea with an average depth of $\sim 60 \mathrm{~m}$. The whole sea area is usually covered by ice during the winter. Average insolation, water temperature, and salinity $(2 \%-6 \%)$ increase from the north to the south.

Stock identification analysis. To establish the basis for stock identification analysis mature river- and sea-spawning whitefish were collected from the Åland Islands and the Finnish west coast (Table 1), and the gill rakers counted as described below. Additional data on gill raker numbers of river- and sea-spawning whitefish were collected from literature or extracted from our own previously obtained data (Table 1).

Mixed whitefish sampling. To sample mixed whitefish populations, the fish were caught at reefs close to Kobba Klintar Island $\left(60^{\circ} 1.8^{\prime} \mathrm{N}, 1^{\circ} 53^{\prime} \mathrm{E}\right)$ located south of the city of Mariehamn at the Åland Islands (Fig. 1). Fish were captured in June, July, and August 2012 with stationary gill nets (1.8 $\mathrm{m}$ deep, $45 \mathrm{~mm}$ mesh size (square measure; knotted square mesh; $0.17 \mathrm{~mm}$ nylon tread diameter) at 2-5 $\mathrm{m}$ depths. Four to six samplings were made every month (1-12 June, 11-20 July, and 7-16 August) when six to twelve fish were caught. The fish weight was between 0.45 and $1.2 \mathrm{~kg}$. The sex and degree of maturation of the fish were determined based on the development stage of the gonads (Nikolsky 1963) into juvenile whitefish (immature, sex unknown), mature whitefish at development stages 1-2 (immature/resting, not to spawn the present year), and 3+ (mature, to spawn the present year). The ratios of female to male and immature to mature fish ranged from $0.9(57 / 62)$ to $2.7(94 / 35)$, respectively.

Gill raker counting. The gills were isolated from the head and the number of gill rakers on the first (outer) gill arch on the left side subsequently counted under a stereomicroscope. The gill rakers were counted independently by two researchers ( $\mathrm{HH}$ and $\mathrm{MH})$, and when necessary recounted until consensus was reached.

Otolith analysis. Strontium concentration was measured in whole sagittal otoliths from an equal number of randomly selected males and females with 27 gill rakers ( $n$ $=10)$ and with 30 gill rakers $(n=10)$. Otoliths were analysed with Varian VISTA-MPX inductively coupled plasma-optical (atomic) emission spectrometer (ICP-OES). Whole otoliths were dissolved in $2 \mathrm{~mL} \mathrm{HNO}_{3}$ in the microwave accelerating system MARS 5 (CEM), $1200 \mathrm{~W}$, $50 \%$ power, $15 \mathrm{~min}, 414 \mathrm{kPa}$ pressure, max temperature $210^{\circ} \mathrm{C}, 10 \mathrm{~min}$ hold time. After mineralization, $8 \mathrm{~mL}$ water was added. For calibration certified ICP reference standards (Fluka) were used.

Data analysis. Student's $t$-test (unpaired two-tailed) was used to compare gill raker number data from river- and sea-spawning whitefish, and otolith strontium concentrations, while ANOVA with Tukey post-hoc test was used to study alteration of gill raker number data over time on whitefish sampled from feeding grounds.

Table 1

Mean number of gill rakers of European whitefish, Coregonus lavaretus, representing sea-spawning-, river-spawning-, and mixed populations sampled at the Åland Islands, along the coast of Finland, and in Finnish rivers

\begin{tabular}{clccccl}
\hline Population & \multicolumn{1}{c}{ Sampling location } & Year & Mean & SD & $n$ & \multicolumn{1}{c}{ Reference } \\
\cline { 2 - 2 } & Kobba Klintar, Åland & 2012 & 28.7 & - & 129 & Presently reported study \\
SPS & Tengsöda, Åland & 2007 & 25.3 & 2.3 & 40 & Presently reported study \\
SPS & Tengsöda, Åland & 2012 & 24.7 & 2.2 & 52 & Presently reported study \\
SPS & Kökar, Åland & $1976-80$ & 27.8 & 2.6 & 100 & Lehtonen 1981 \\
SPS & Pyhäranta, Uusikaupunki & 2011 & 27.6 & 2.6 & 64 & Presently reported study \\
SPS & Pori, Pori & $1976-80$ & 26.6 & 1.9 & 200 & Lehtonen 1981 \\
SPR & Tornio River, Tornio & 1961 & 29.7 & 2.2 & 38 & Himberg 1970 \\
SPR & Tornio River, Tornio & $1998-9$ & 30.3 & 2.3 & 89 & Himberg unpublished \\
SPR & Tornio River, Tornio (July) & 2013 & 30.2 & 1.8 & 47 & Presently reported study \\
SPR & Simo River, Simo & $<1981$ & 30.1 & 1.8 & 31 & Lehtonen 1981 \\
SPR & Ii River, Ii & 1962 & 30.1 & 2.3 & 84 & Himberg 1970 \\
SPR & Oulu River, Oulu & $<1981$ & 28.6 & 2.2 & 75 & Lehtonen 1981 \\
SPR & Kokemäki River, Pori & 2011 & 30.0 & 2.1 & 65 & Presently reported study \\
SPR & Aura River, Turku & 1998 & 30.8 & 1.7 & 20 & Himberg unpublished \\
SPR & Kisko River, Salo & 1994 & 29.8 & 2.1 & 31 & Himberg unpublished \\
\hline
\end{tabular}

Detailed locations are shown in Fig. 1; MPS = mixed population, sea (summer), SPS = spawning population, sea (autumn), SPR = spawning population, river (autumn). 
Table 2

Frequency distribution of the gill raker number of European whitefish, Coregonus lavaretus, from Kobba Klintar,

Åland Islands, captured in June, July, and August 2012

\begin{tabular}{|c|c|c|c|c|c|c|c|c|}
\hline \multirow{3}{*}{$\begin{array}{c}\text { Gill raker } \\
\text { number }\end{array}$} & \multicolumn{8}{|c|}{ Frequency } \\
\hline & \multicolumn{2}{|c|}{ Total $(n=129)$} & \multicolumn{2}{|c|}{ June $(n=34)$} & \multicolumn{2}{|c|}{ July $(n=61)$} & \multicolumn{2}{|c|}{ August $(n=34)$} \\
\hline & {$[\%]$} & $n$ & {$[\%]$} & $n$ & {$[\%]$} & $n$ & {$[\%]$} & $n$ \\
\hline 23 & 1.6 & 2 & - & - & 3.3 & 2 & - & - \\
\hline 24 & 0.8 & 19 & 2.9 & 1 & - & - & - & - \\
\hline 25 & 4.7 & 6 & 2.9 & 1 & 1.6 & 1 & 11.8 & 4 \\
\hline 26 & 7.0 & 9 & 5.9 & 2 & 6.6 & 4 & 8.8 & 3 \\
\hline 27 & 19.4 & 25 & 5.9 & 2 & 21.3 & 13 & 29.4 & 10 \\
\hline 28 & 12.4 & 16 & 2.9 & 1 & 16.4 & 10 & 14.7 & 5 \\
\hline 29 & 15.5 & 20 & 8.8 & 3 & 24.6 & 15 & 5.9 & 2 \\
\hline 30 & 19.4 & 25 & 41.2 & 14 & 13.1 & 8 & 8.8 & 3 \\
\hline 31 & 10.1 & 13 & 11.8 & 4 & 8.2 & 5 & 11.8 & 4 \\
\hline 32 & 6.2 & 8 & 8.8 & 3 & 4.9 & 3 & 5.9 & 2 \\
\hline 33 & 0.8 & 1 & 2.9 & 1 & - & - & - & - \\
\hline 34 & 2.3 & 3 & 5.9 & 2 & - & - & 2.9 & 1 \\
\hline$\leq 28$ & 46 & & 21 & & 48 & & 65 & \\
\hline$\geq 29$ & 54 & & 79 & & 52 & & 35 & \\
\hline Mean & & 28.7 & & 29.7 & & 28.4 & & 28.2 \\
\hline
\end{tabular}

The mean number of gill rakers in June was significantly higher ( $P=0.01$ and 0.008 , respectively, ANOVA with Tukeys post-hoc test) than the number in July and August.

\section{RESULTS}

Gill raker number data of eleven river- and sea-spawning whitefish populations at the Finnish west coast and the Åland Islands are presented in Table 1. The weighted mean number of gill rakers of river-spawners is $29.87(\mathrm{SD}=2.14$, $n=480$ ) and the corresponding number of gill rakers of sea-spawners is $26.67(\mathrm{SD}=2.21, n=456)$. The difference between the two groups was highly significant $(t=22.50$, df $=934, P<0.0001)$. The means differed by $3.20(2.92-3.48$, $95 \% \mathrm{CL}$ ) indicating the groups are well separated.

Based on the weighted mean values of spawning reference populations river-spawning whitefish was defined to have $\geq 29$ gill rakers and sea-spawning whitefish $\leq 28$ gill rakers, respectively.

To study mixed whitefish populations, a total of 129 whitefish were sampled at feeding grounds at the Åland Islands during a three-month period. The gill raker number ranged from 23 to 34 (mean: 28.7) (Table 2) The gill raker number distribution showed two modes, at 27 and 30 rakers (Table 2). Altogether, 54\% of the whitefish had $\geq 29$ rakers (Table 2 ). The distribution of gill raker counts in the catch from June showed a major peak at 30, in July two peaks at 27 and 29, and in August a major peak at 27 (Table 2). ANOVA indicated differences between gill raker number means in samples from June, July, and August $\left(F_{2,126}=5.73, P=0.004\right)$. Pairwise comparison using Tukey post-hoc test showed that the weighted mean number of gill rakers in whitefish caught in June (29.7) was significantly higher $(P=0.01$ and 0.008 , respectively) than the number in July (28.4) and in August (28.2) (Table 2).

Otolith strontium concentration was higher $(t=2.09$, $\mathrm{df}=18, P=0.04)$ in whitefish having 27 gill rakers $(3.86$ $\left.\pm 0.30 \mathrm{mg} \cdot \mathrm{g}^{-1}, n=10\right)$, compared to those having 30 gill rakers $\left(3.54 \pm 0.35 \mathrm{mg} \cdot \mathrm{g}^{-1}, n=10\right)$.

\section{DISCUSSION}

The presented analysis on gill raker number data from river- and sea-spawning whitefish stocks shows that gill raker counting can be used to estimate the proportion of river- and sea-spawning whitefish, as these whitefish forms cannot be distinguished based on outer features. Our results verify previous indications that the mean number of gill rakers is higher in river-spawning whitefish populations than in sea-spawning ones at the Åland Islands including the Archipelago Sea (Himberg 1970, 1978, Lehtonen and Himberg 1979, Lehtonen 1981, Lehtonen and Böhling 1988, Ozerov et al. 2015). Otolith microchemistry analysis supported the utility of the gill raker counting method. In the material collected at reefs close to Kobba Klintar, Åland Islands (Fig. 1), the whitefish with 30 gill rakers had significantly lower otolith strontium concentration than the specimens with 27 gill rakers. The lower strontium concentration in otoliths of fish with high gill raker number is apparently due to the time of this river-spawning whitefish spent in water with low salinity as fry and juvenile, and due to possible spawning migrations as mature. Strontium concentration of seawater increases with increasing salinity (Campana 1999, Elsdon et al. 2008), and this salinity related strontium level is reflected in otolith strontium concentrations (Secor and Rooker 2000, Zimmermann 2005, Engstedt et al. 2010, Macdonald and Crook 2010, Engstedt et al. 2012). In accordance with our results, the otolith strontium concentration in sea spawning whitefish (Mariehamn) caught at spawning grounds is significantly higher than in otoliths of river spawning whitefish (Kokemäki and Tornio rivers) (Hägerstrand, unpublished results).

Gill raker number data indicated temporal alteration of river- and sea-spawning whitefish at the feeding 
grounds close to Kobba Klintar, Åland Islands (Fig. 1). The mean number of gill rakers of the sampled whitefish was 28.7 (Table 1 and 2). This value was intermediate compared with the mean gill raker number of sea- and river-spawning whitefish stocks (Table 1), i.e., typical for a mixed sample (Himberg 1978, Lehtonen 1981, Himberg 1995). When the sampled whitefish was separated into three groups; fish caught in June, July, and August, a marked decrease in gill raker number over the period was revealed. The mean number of gill rakers of whitefish caught in June was significantly higher (29.7) compared to fish caught in July (28.4) and August (28.2) (Table 2). The results indicate that both river-and sea-spawning whitefish with a different mean number of gill rakers occurred on the reefs at different times during the summer. Apparently, river-spawning whitefish $(\geq 29$ gill rakers) dominated $(\sim 79 \%)$ in the beginning of the summer (June), but their frequency decreased through July until August. Sea-spawning whitefish $(\leq 28$ gill rakers) dominated $(\sim 65 \%)$ the sampling sites by the end of the summer (August). The reduction in the ratio of river-spawning whitefish from June to July and August on the sampling site could be due to migration towards spawning rivers. The migration of river-spawning whitefish from the feeding areas to the northern rivers starts in June-July (Lindroth 1957, Wikgren 1962, Lind and Kaukoranta 1974, Lehtonen 1981). The time of departure is probably dependent on the distance to the spawning rivers (Lehtonen 1981). Immature fish may not migrate. Some immature high gill raker number whitefish remained at the sampling site throughout the summer (Table 3). This is consistent with previous findings indicating that river-spawning whitefish may stay in the south for feeding for several (3-5), years until maturation (Lehtonen 1981). The presence of mature males with high gill raker number in the August catches raises the question whether river-spawning males may spawn in nearby rivers like the Aura and Kisko rivers (Fig. 1), or in the sea. While homing may be less pronounced in males than in females (Huusko and Grotnes 1988), the destruction of traditional spawning locations and potential homogenization of river- and sea-spawning whitefish gene pools as a result of stocking activities may have affected the homing instinct of river-spawning whitefish. Sea-spawning whitefish dominated the catches in August. Sea-spawning whitefish has short distance to their scattered spawning locations at the seashores around the Åland Islands. It is unclear whether water temperature preference, search for a particular prey or competition for food influence the spatiotemporal occurrence of the two main whitefish groups at the feeding reefs. Abundant annual stocking of mainly river but also sea-spawning whitefish has for several decades been undertaken along the Finnish west coast, including the Archipelago Sea (Anonymous 2013). At the Åland Islands only sea-spawning whitefish has been stocked (Leskelä 2008). Whitefish to be stocked is typically raised in freshwater. It is not known how the raising conditions affect otolith elemental concentrations of whitefish. Low mean values of strontium concentrations in otoliths in high gill

Frequency of distribution of the gill raker number of European whitefish, Coregonus lavaretus,

Table 3 caught at Kobba Klintar Åland Islands in 2012 in relation to maturity stage and sex

\begin{tabular}{|c|c|c|c|c|c|c|c|c|c|c|}
\hline \multirow{3}{*}{ Month } & \multirow{3}{*}{$\begin{array}{c}\text { Gill raker } \\
\text { number }\end{array}$} & \multirow{3}{*}[\%]{} & \multirow{3}{*}{$n$} & \multirow{3}{*}{$\begin{array}{l}\text { Maturity } \\
\text { stage }\end{array}$} & \multicolumn{6}{|c|}{ Frequency } \\
\hline & & & & & \multicolumn{2}{|c|}{ Female } & \multicolumn{2}{|c|}{ Male } & \multicolumn{2}{|c|}{ Juvenile } \\
\hline & & & & & {$[\%]$} & $n$ & {$[\%]$} & $n$ & {$[\%]$} & $n$ \\
\hline \multirow[t]{6}{*}{ June } & $23-34$ & 100 & 34 & $1-2$ & 41 & 14 & 24 & 8 & 24 & 8 \\
\hline & & & & $3+$ & - & - & 12 & 4 & - & - \\
\hline & $\geq 29$ & 79 & 27 & $1-2$ & 48 & 13 & 26 & 7 & 15 & 4 \\
\hline & & & & $3+$ & - & - & 11 & 3 & - & - \\
\hline & $\leq 28$ & 21 & 7 & $1-2$ & 14 & 1 & 14 & 1 & 57 & 4 \\
\hline & & & & $3+$ & - & - & 14 & 1 & - & - \\
\hline \multirow[t]{6}{*}{ July } & $23-34$ & 100 & 61 & $1-2$ & 33 & 20 & 34 & 21 & - & - \\
\hline & & & & $3+$ & 8 & 5 & 25 & 15 & - & - \\
\hline & $\geq 29$ & 52 & 32 & $1-2$ & 28 & 9 & 34 & 11 & - & - \\
\hline & & & & $3+$ & 13 & 4 & 25 & 8 & - & - \\
\hline & $\leq 28$ & 48 & 29 & $1-2$ & 38 & 11 & 34 & 10 & - & - \\
\hline & & & & $3+$ & 3 & 1 & 24 & 7 & - & - \\
\hline \multirow[t]{6}{*}{ August } & $23-34$ & 100 & 34 & $1-2$ & 38 & 13 & 15 & 5 & 6 & 2 \\
\hline & & & & $3+$ & 15 & 5 & 26 & 9 & - & - \\
\hline & $\geq 29$ & 35 & 12 & $1-2$ & 33 & 4 & 8 & 1 & 8 & 1 \\
\hline & & & & $3+$ & 8 & 1 & 42 & 5 & - & - \\
\hline & $\leq 28$ & 65 & 22 & $1-2$ & 41 & 9 & 18 & 4 & 5 & 1 \\
\hline & & & & $3+$ & 18 & 4 & 18 & 4 & - & - \\
\hline
\end{tabular}

Maturity stages: 1-2 = immature/resting, not spawning this year, $3+=$ mature, spawning this year; and sex ("Juvenile" included all specimens which were immature, with sex unknown, not spawning this year). 
raker number whitefish may occur both in wild-born and stocked fish of the river spawning type. To distinguish between stocked and wild-born whitefish is an important issue that remains to be clarified.

\section{ACKNOWLEDGEMENTS}

The project was supported by the Swedish Cultural Foundation in Finland, the Åland Provincial Government (Beslut Nr 209 N30), the Academy of Finland, the Estonian Ministry of Education and Research (Inst. Res. Fund. project IUT8-2) and the European Fisheries Fund. The authors are grateful to Mr Piotr Hägerstrand and $\mathrm{Mr}$ Benny Holmström ( land Islands) for providing fish. The authors declare no conflict of interest.

\section{REFERENCES}

Amundsen P.-A., Bøhn T., Våga G.H. 2004. Gill raker morphology and feeding ecology of two sympatric morphs of European whitefish (Coregonus lavaretus). Annales Zoologici Fennici 41 (1): 291-300.

Anonymous 2010. Ecosystem health of the Baltic Sea 2003-2007. HELCOM initial holistic assessment. Baltic Sea Environment Proceedings. No. 122. HELCOM.

Anonymous 2013. Coregonus albula; species information sheet. In: HELCOM http://www.helcom.fi

Bernatchez L., Renaut S., Whiteley A.R., Derome N., Jeukens J., Landry L., Lu G., Nolte A.W., Østbye K., Rogers S.M., St-Cyr J. 2010. On the origin of species: Insights from the ecological genomics of lake whitefish. Philosophical Transactions of the Royal Society B 365: 1783-1800.

DOI: $10.1098 /$ rstb.2009.0274

Campana S.E. 1999. Chemistry and composition of fish otoliths: Pathways, mechanisms and applications. Marine Ecology Progress Series 188: 263-297.

DOI: $10.3354 /$ meps 188263

Dahr E. 1947. Biologiska studier över siken, Coregonus lavaretus Linné, vid mellansvenska Östersjökusten. [Biological studies of the whitefish, Coregonus lavaretus Linné, at the middle Swedish Baltic Sea coast.] Meddelanden frản Statens undersöknings- och försöksanstalt för sötvattensfisket, Kungliga Lantbruksstyrelsen 28: 1-79. [In Swedish.]

Doubleday Z.A., Izzo C., Woodcock S.H., Gillanders B.M. 2013. Relative contribution of water and diet to otolith chemistry in freshwater fish. Aquatic Biology 18 (3): 271-280.

DOI: $10.3354 / \mathrm{ab} 00511$

Elsdon T.S., Wells B.K., Campana S.E., Gillanders B.M., Jones C.M., Limburg K.E., Secor D.H., Thorrold S.R., Walther B.D. 2008. Otolith chemistry to describe movements and life-history parameters of fishes: Hypotheses, assumptions, limitations and inferences. Pp. 297-330. In: Gibson R.N., Atkinson R.J.A., Gordon J.D.M. (eds.) Oceanography and Marine Biology: An Annual Review Vol. 46.

DOI: $10.1201 / 9781420065756 . c h 7$.
Engstedt O., Koch-Schmidt P., Larsson P. 2012. Strontium (Sr) uptake from water and food in otoliths of juvenile pike (Esox lucius L.). Journal of Experimental Marine Biology and Ecology 418-419: 69-74.

DOI: $10.1016 /$ j.jembe.2012.03.007

Engstedt O., Stenroth P., Larsson P., Ljunggren L., Elfman M. 2010. Assessment of natal origin of pike (Esox lucius) in the Baltic Sea using Sr:Ca in otoliths. Environmental Biology of Fishes 89 (3-4): 547-555. DOI: $10.1007 / \mathrm{s} 10641-010-9686-\mathrm{X}$

Himberg M. 1970. A systematic and zoogeographical study of some north European coregonids. Pp. 219250. In: Lindsey C., Woods C. (eds.) Biology of coregonid fishes. Manitoba University Press, Winnipeg, MB, Canada.

Himberg M. 1978. Sikarna i vårt havsområde. [The whitefish in our sea area.] Åbo Akademi-Ålands landskapsstyrelse. Husö Biologiska Station Meddelanden 2: 2-3. [In Swedish.]

Himberg M. 1995. Sikens biologi och lekplatser i Skärgårds och Bottenhavet. [Whitefish biology and spawning locations in the Archipelago Sea and Gulf of Bothnia.] Kala- ja riistahallinnon julkaisuja 16: 2-21. [In Swedish.]

Hudd R., Veneranta L., Vanhatalo J. 2013. Havslekande sikens och siklöjans yngelproduktionsområden. [The reproduction areas of sea-spawning whitefish and vendace.] Vilt- och fiskeriforskningsinstitutes arbetsrapporter, 7: 1-38. [In Swedish.]

Huusko O., Grotnes P. 1988. Population dynamics of the anadromous whitefish, Coregonus lavaretus (L.), of the river Kiiminkijoki, Finland. Finnish Fisheries Research 9: 245-254.

Jokikokko E., Huhmarniemi A., Leskelä A., Vähä V. 2012. Migration to the sea of river spawning whitefish (Coregonus lavaretus L.) fry in the northern Baltic Sea. Advances in Limnology 63: 117-125. DOI: $10.1127 /$ advlim/63/2012/117

Järvi T.H. 1928. Über die Arten und Formen der Coregonen s. str. in Finland. Acta Zoologica Fennica 5: 1-259.

Kirpichnikov V.S. 1981. Genetic Bases of Fish Selection. Springer-Verlag, Berlin-Heidelberg-New York.

Lehtonen H. 1981. Biology and stock assessments of coregonoids by the Baltic coast of Finland. Finnish Fisheries Research 3: 31-83.

Lehtonen H., Böhling P. 1988. Management of the whitefish (Coregonus lavaretus L. s.l. fishery in the Gulf of Bothnia. Finnish Fisheries Research 9: 373-387.

Lehtonen H., Himberg M. 1979. Sikbestånd och sikfångster vid våra kuster. [Whitefish stocks and catches at our coasts.] Fiskeritidskrift för Finland 23 (4): 68-72. [In Swedish.]

Lehtonen H., Himberg M. 1992. Baltic Sea migration patterns of anadromous, Coregonus lavaretus (L.) s. str., and sea-spawning European whitefish, C.l. widegreni Malmgren. Polish Archives of Hydrobiology 39 (3-4): 463-472. 
Leskelä A., Jokikokko E., Huhmarniemi A. 2009. Perämeren vaellussiikaistutusten tulokset. [Results from the stocking of river-spawning whitefish in the Gulf of Bothnia.] Riista- ja kalatalouden tutkimuslaitos, Helsinki No. 7. [In Finnish.]

Lind E.A., Kaukoranta E. 1974. Characteristics, population structure and migration of the whitefish, Coregonus lavaretus (L.) in the Oulujoki River. Ichthyologia Fennica Borealis 4: 160-217.

Lindroth A. 1957. A study of the whitefish (Coregonus) of the Sundsvall Bay district. Institute of Freshwater Research, Drottningholm: Report No. 38: 70-108.

Macdonald J.I., Crook D.A. 2010. Variability in $\mathrm{Sr}: \mathrm{Ca}$ and $\mathrm{Ba}: \mathrm{Ca}$ ratios in water and fish otoliths across an estuarine salinity gradient. Marine Ecology Progress Series 413: 147-161. DOI: $10.3354 / \operatorname{meps} 08703$

Nikolsky G.V. 1963. The ecology of fishes. Academic Press, London, UK.

Ozerov M.Y., Himberg M., Aykanat T., Sendek D.S., Hägerstrand H., Verliin A., Krause T., Olsson J., Primmer C.R., Vasemägi A. 2015. Generation of a neutral $F_{\mathrm{ST}}$ baseline for testing local adaptation on gill raker number within and between European whitefish ecotypes in the Baltic Sea basin. Journal of Evolutionary Biology 28 (5): 1170-1183.

DOI: $10.1111 /$ jeb. 12645

Secor D.H., Rooker J.R. 2000. Is otolith strontium a useful scalar of life cycles in estuarine fishes? Fisheries Research 46 (1-3): 359-371.

DOI: $10.1016 / \mathrm{S} 0165-7836(00) 00159-4$

Siwertsson A., Knudsen R., Amundsen P.-A. 2012. Temporal stability in gill raker numbers of subarctic European whitefish populations. Advances in Limnology 63: 229-240.

DOI: $10.1127 /$ advlim/63/2012/229
Svärdson G. 1957. The coregonid problem. VI. The palearctic species and their intergrades. Institute of Freshwater Research Drottningholm: Report No. 38: 267-356.

Valtonen T. 1970. The selected temperature of Coregonus nasus (Pallas), sensu Svärdson, in natural waters compared with some other fish. Pp. 346-362. In: Lindsey C., Woods C. (eds.) Biology of coregonid fishes. Manitoba University Press, Winnipeg, MB, Canada.

Vanhatalo J., Veneranta L., Hudd R. 2012. Species distribution modeling with Gaussian processes: A case study with the youngest stages of sea spawning whitefish (Coregonus lavaretus L. s.l.) larvae. Ecological Modelling 228: 49-58.

DOI: $10.1016 /$ j.ecolmodel.2011.12.025

Veneranta L., Hudd R., Vanhatalo J. 2013. Reproduction areas of sea-spawning coregonids reflect the environment in shallow coastal waters. Marine Ecology Progress Series 477: 231-250.

DOI: $10.3354 /$ meps 10169

Verliin A., Kotta J., Orav-Kotta H., Saks L., Vetemaa M. 2011. Food selection of Coregonus lavaretus in a brackish water ecosystem. Journal of Fish Biology 78 (2): 540-551. DOI: $10.1111 /$ j.1095-8649.2010.02870.x

Wikgren B.-J. 1962. Resultaten av sikmärkningar inom Åland och vid Luvia. [Results from whitefish tagging at the Åland Islands and Luvia.] Åbo Akademi-Ålands landskapsstyrelse. Husö Biologiska Station Meddelanden 3: 1-26. [In Swedish.]

Zimmerman C.E. 2005. Relationship of otolith strontium-to-calcium ratios and salinity: Experimental validation for juvenile salmonids. Canadian Journal of Fisheries and Aquatic Sciences 62 (1): 88-97. DOI: $10.1139 /$ F04-182

Received: 13 October 2014

Accepted: 3 February 2015

Published electronically: 30 June 2015 